\title{
Modelling Non-motor Symptoms of Parkinson's Disease: AAV Mediated Overexpression of Alpha-synuclein in Rat Hippocampus and Basal Ganglia
}

\author{
Parkinson Hastalığında Motor Dışı Semptomların Modellenmesi: Sıçan Hipokampüsünde \\ ve Bazal Gangliyonlarında Alfa-sinükleinin AAV Aracılı Aşırı Ífadesi
}

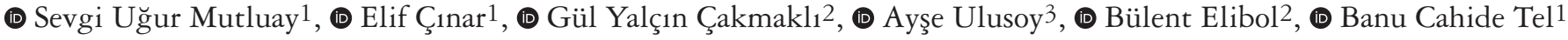 \\ 1 Hacettepe University Faculty of Pharmacy, Department of Pharmacology, Ankara, Turkey \\ ${ }^{2}$ Hacettepe University Faculty of Medicine, Department of Neurology, Ankara, Turkey \\ ${ }^{3}$ German Center for Neurodegenerative Diseases (DZNE) Bonn, Germany
}

\begin{abstract}
Objective: Our aim was to investigate the relation between unilateral hippocampal and/or nigral alpha-synucleinopathy and cognitive dysfunction, anxiety and anhedonia.

Materials and Methods: Female Sprague-Dawley rats were stereotactically injected adeno-associated viruses carrying alpha-synuclein ( $\alpha$-syn) into unilateral dentate gyrus (DG), substantia nigra (SN) or both SN + DG. The animals were tested for motor functions and memory, spatial learning, anxiety and hedony. Levels of $\alpha$-syn and synaptophysin were evaluated by Western blot (WB) analysis.

Results: In apomorphine-induced rotation test, a mild motor dysfunction was found in SN- $\alpha$-syn group compared to control. DG- $\alpha$-syn group showed memory impairment in novel object recognition test. All the $\alpha$-syn injected groups spent more time to find the platform compared to controls in Morris water maze but this difference did not reach statistical significance. DG- $\alpha$-syn group consumed more sucrose solution in sucrose consumption test and spent more time on the open arm in elevated plus maze, while the opposite was observed in $\mathrm{SN}-\alpha$-syn group compared to controls. We showed $\alpha$-syn protein expression in the injected areas of all $\alpha$-syn groups by WB and immunohistochemical staining. In WB analysis, both hippocampal and striatal synaptophysin expression levels were lower in the $\alpha$-syn groups compared to controls.

Conclusion: Parkinson's disease (PD) is characterized by both motor and non-motor symptoms (NMS). However, an animal model recapitulating NMS with the background of dopaminergic denervation is still lacking. This model may help to investigate hippocampal $\alpha$-syn pathology correlated especially with cognitive dysfunction and other NMS of PD.
\end{abstract}

Keywords: Parkinson's disease, adeno-associated viral vector, behavioral tests, hippocampus, substantia nigra

$\ddot{\mathrm{Oz}}$

Amaç: Amacımız, oluşturulan unilateral hipokampal ve/veya nigral alfa-sinükleinopati ile bilişsel disfonksiyon, anksiyete ve anhedoni arasındaki ilişkiyi araştırmaktır.

Gereç ve Yöntem: Dişi Sprague-Dawley sıçanların dentat girus (DG) ve substantia nigra (SN) veya her ikisine DG + SN unilateral olarak adeno-ilişkili virüsaracılı alfa-sinüklein $(\alpha$-sin) strereotaksik olarak enjekte edildi. Hayvanlar, motor işlevlerin yanısıra hafıza, uzaysal öğrenme, anksiyete ve hedoninin incelenmesi amacı ile test edildiler. $\alpha$-sin ve sinaptofizin düzeyleri Western blot (WB) analizleri ile değerlendirildi.

Bulgular: Apomorfin ile indüklenen dönme testinde, $\mathrm{SN}-\alpha$-sin grubunda kontrol grubuna kıyasla hafif motor bozukluk oluştuğu gözlendi. DG-a-sin grubunda yeni nesne tanıma testi ile hafıza bozukluğu olduğu görüldü. $\alpha$-sin enjeksiyonu gerçekleştirilmiş bütün gruplarda Morris su labirenti testinde platformu bulma süresi kontrol grubuna kıyasla daha uzun olsa da gruplar arasındaki bu fark istatistiksel anlamlılığa ulaşmadı. DG- $\alpha$-sin grubunun sükroz tercih testinde sükroz çözeltisini daha çok tercih ettiği ve yükseltilmiş artı labirenti testinde açık kolda daha çok vakit geçirdiği gözlenirken, SN-a-sin grubunun ise bu testlerde DG- $\alpha$-sin grubunun tam tersi yönde davranış gösterdiği görüldü. $\alpha$-sin proteininin bütün enjeksiyon bölgelerinde ifade edildiği, WB yöntemi ve immünohistokimyasal boyama ile gösterildi. Yine WB analizi ile $\alpha$-sin enjekte edilmiş grupların hipokampus ve striatumlarında sinaptofizin düzeylerinin kontrollere göre daha az olduğu bulundu.

Sonuç: Parkinson hastalığ $\breve{1}_{(\mathrm{PH})}$ motor ve motor-dışı semptomlarla (NMS) karakterize bir hastalıktır, fakat dopaminerjik denervasyon zemininde NMS'lerin gösterildiği bir hayvan modeli henüz geliştirilememiştir. Oluşturulan bu model, PH'de bilişsel disfonksiyon ve NMS'lerin özellikle hipokampal $\alpha$-sin patolojisi temelinde araştırılmasına yardım edebilir.

Anahtar Kelimeler: Parkinson hastalı̆̆ı, adeno-ilişkili viral vektör, davranış deneyleri, hipokampus, substantia nigra

Address for Correspondence/Yazışma Adresi: Sevgi Uğur Mutluay, Hacettepe University Faculty of Pharmacy, Department of Pharmacology, Ankara, Turkey Phone: +90312305 1088 E-mail: sevgimutluay@gmail.com ORCID: orcid.org/0000-0002-8794-6397

Received/Geliş Tarihi: 06.11.2020 Accepted/Kabul Tarihi: 23.12.2020

${ }^{\circ}$ Copyright 2020 by Turkish Neurological Society

Turkish Journal of Neurology published by Galenos Publishing House. 


\section{Introduction}

Parkinson's disease (PD) is a progressive neurodegenerative disorder characterized by loss of dopaminergic neurons in substantia nigra (SN) pars compacta as well as widespread expression of Lewy bodies (LB) throughout the brain. Clinical diagnosis is mainly based on the motor symptoms such as tremor, rigidity, postural instability, and bradykinesia. However, there are also non-motor symptoms (NMS) that can be disabling as much as motor symptoms such as neuropsychiatric, sensorial and autonomic disorders. NMS may precede the onset of motor symptoms or occur at any stage of the disease. Hippocampus is thought to be implicated in cognitive decline, anxiety, depression and anhedonia observed in PD (1). Alpha-synuclein $(\alpha$-syn) is recognized as the key element in pathogenesis of PD. Misfolding and aggregation of the protein lead to formation of toxic oligomers or fibril species and finally Lewy inclusions (2).

For the last several decades there have been many efforts to develop experimental models of PD. Toxin-based models represent end-stage $\mathrm{PD}$, yet they are far from demonstrating the progressive nature of the disease and LB pathology (3). Transgenic models enable the widespread expression of $\alpha$-syn in the brain. However, results from transgenic mice models are controversial and, most importantly, the selective and progressive nigrostriatal neuron death cannot be achieved (3). Fibril models of $\alpha$-syn were developed mainly to explore the mechanisms of $\alpha$-syn propagation (4). Although neurodegeneration and neuroinflammation were also observed in fibril models (5), the behavioral component of the disease has not been investigated hence the controversy exsists over results and further validation of the model is necessary.

Viral vectors are effective tools to create the pathology like progressive death of nigral dopaminergic neurons andin many studies, it has been shown that $\alpha$-syn inclusions in the desired brain region accompanies motor dysfunction $(6,7,8,9,10,11,12,13)$. All of these models have expanded our knowledge about PD etiology, underlying molecular mechanisms and its relation with genetics, while none of them has been capable of replicating all aspects of the disease collectively.

To date, in studies using adeno-associated viruses (AAV), the target has mainly been the nigrostriatal system, which is not likely to lead to development of NMS (14). More recently, there have been attempts to investigate the effects of $\alpha$-syn overexpression in different brain regions other than nigrostriatal system $(15,16,17,18,19,20)$. However, number of those studies is limited and hippocampal synucleinopathy is yet to be elaborated. Therefore, in this study, we aimed to develop an animal model that represented both motor and NMS together with pathological changes at the cellular level. For this aim, unilateral stereotactic injections of AAV virus type (AVV6) carrying $\alpha$-syn were performed into dentate gyrus (DG) of hippocampus, SN pars compacta or both areas together. Motor and non-motor impairments, as well as pattern of $\alpha$-syn expression in target structures, levels of synaptic and neuronal markers were evaluated.

\section{Materials and Methods}

\section{Experimental Procedures}

Animals

Female Sprague-Dawley rats (aged 8-10 weeks, weighing 220$280 \mathrm{~g})$ were used $(\mathrm{n}=50)$. Rats were brought to laboratory at least 2 days before the experiments and kept under standard conditions with ad libitum access to food and water, except during sucrose preference test. All experimental procedures were approved by Hacettepe University Local Animal Ethics Committee (decision number: 2014/44-10) and performed in compliance with national and local animal care and use guidelines.

AAV-carrying $\alpha$-syn was unilaterally injected into DG $(n=12)$, $\mathrm{SN}(\mathrm{n}=12)$ or $\mathrm{SN}+\mathrm{DG}(\mathrm{n}=12)$. Further, 14 animals were used as naive controls. Fourteen weeks after the injection, animals were tested for motor and behavioral changes. In vivo experiments lasted three weeks (Figure 1A), right after that, at the $17^{\text {th }}$ week, in each group, animals were divided into 2 subgroups to be analyzed by either immunohistochemistry [(IHC), $n=25]$ or Western blot [(WB), $n=25]$.

\section{Surgery}

Animals were deeply anesthetized with a mix of ketamine and xylazine and placed in a stereotaxic frame (Stoelting, USA) with the toothbar set to $-2.3 \mathrm{~mm}$ (Paxinos and Watson) (21). Animals received unilateral injections in either $\mathrm{SN}$ or $\mathrm{DG}$ alone, or $\mathrm{SN}$ and DG together. Coordinates for $\mathrm{SN}$ injections were anterioposterior (AP): $-5.2 \mathrm{~mm}$ and mediolateral (ML): $-2.0 \mathrm{~mm}$ relative to bregma and dorsoventral [(DV): $-7.2 \mathrm{~mm}]$ from dura, and for DG injections were AP: $-5 \mathrm{~mm}, \mathrm{ML}:-3.5 \mathrm{~mm}$ relative to bregma and DV: -2.6 $\mathrm{mm}$ from dura. Ten $\mu \mathrm{l}$ Hamilton syringe fitted with a glass capillary was used for injections. Viral vectors were purchased from Prof. Kirik's Laboratory (BRAINS Unit, Lund University). $2 \mu \mathrm{l}$ of vector suspension containing rAAV6- $\alpha$-syn $(5.9 \mathrm{E} 13 \mathrm{vg} / \mathrm{ml})$ was injected slowly at a rate of $0.2 \mu \mathrm{l} /$ minute as described previously (22).

\section{Behavioral Tests}

Behavioral tests were conducted starting from $14^{\text {th }}$ week after the injection, that was required amount of time for gene expression in target areas, with 2-day intervals between each test (Figure 1A). Animals were handled for 2 days before starting behavioral tests, to reduce the anxiety. Each behavioral test was performed at the same time period of the day (Figure 1B).

\section{Cylinder Test (CT)}

For evaluating motor asymmetry expected due to unilateral injection, CT was performed and number of contralateral forelimb contacts on the cylinder wall was analyzed. A glass cylinder (25 $\mathrm{cm}$ in diameter) and three mirrors to see touches from all angles were used. The room was kept dim. Rats were put in the cylinder and recorded for ten minutes with a video camera (Sony Handycam DCR-HC37). Recordings were analyzed by a blinded observer. If both limbs touched the wall at the same time, it was counted for both sides. The ipsilateral and contralateral contacts were expressed as the percentage of total number of contacts.

\section{Open Field Apomorphine-induced Rotation Test (AIRT)}

In unilateral dopaminergic denervation, dopamine receptors become supersensitive and apomorphine causes contralateral turning behavior in the animals. This was assessed by putting 
animals in a black, open box $(40 \times 40 \times 30 \mathrm{~cm})$ after subcutaneous injection of $1 \mathrm{mg} / \mathrm{kg}$ apomorphine and recorded for 40 minutes with a video camera tracking system. Partial turning behavior $\left(45^{\circ}\right)$ of the rats were analyzed. Results were given as average number of contralateral partial $\left(45^{\circ}\right)$ rotations per each group.

\section{Novel Object Recognition (NOR)}

For evaluating short-term memory, NOR test was applied as described previously (22). In short, a black, open box was used. After 2 days of habituation, on the third day, two identical objects were placed in the box and rats were allowed to familiarize with these for 10 minutes. One hour later one of the objects was replaced with a new one and behaviors of rats were recorded for 5 minutes using a video tracking system (EthoVision ${ }^{\circledR} \mathrm{XT}$, Noldus IT, Holland). Ratio of the time spent with the novel object to the total time spent with the novel and the familiar objects was used. Additionally, ratio of the frequency of visits to the novel object to the frequency of total visits to the novel and familiar objects was used as another measure of short-term memory.

\section{Morris Water Maze (MWM)}

Animals were tested for spatial learning and memory in MWM as previously described (22). The maze consisted of a pool, and a hidden platform at northeast direction of the theoretically defined four quadrants. The training was conducted on first four consecutive days and each day in 4 sessions. At each session, rats were put into the maze at different starting points (N, W, S, E) and expected to find the hidden platform following the external cues. Cut-off time was 120 seconds. Latency to find the platform and time spent in quadrants were calculated as averages. On day 5, the platform was removed and a probe trial was performed. All rats were put into the maze from south and expected to find the former place of the hidden platform in 90 seconds. Trials were recorded using a video camera tracking system (VideoMot2, TSE Systems, Germany). Latencies to find the former place of platform and time spent in each quadrant were analyzed.

\section{Sucrose Preferance Test (SPT)}

For assessing hedonia, SPT was performed; as sucrose solution consumption was reduced in rats exposed to chronic stressors and this represented anhedonia. For this test, rats were placed in seperate cages as per their groups. For the first two days, rats were given both tap water and $2 \%$ sucrose solution for them to habituate to sucrose solution. At the end of day 1 , the sides of the bottles were switched to prevent side-preference bias. At the end of day 2, all bottles were removed from the cages and rats were deprived of water for 8 hours. Pre-weighed bottles, containing tap water or $2 \%$ sucrose solution, were placed on the cages for 12 hours then their sides were switched for another 12 hours. At the end of 24 hour, bottles were weighed. Results were given as percentage of the $2 \%$ sucrose solution consumption to total liquid consumption.

\section{Elevated Plus Maze (EPM)}

To assess anxiety-like behavior, EPM test was performed as described earlier (22). Plus-shaped maze consisted of 2 closed and 2 open arms, all accessible from the centre. Rats were put in the centre facing the closed arm and then were recorded for 5 minutes with the video tracking system. Time spent in centre, open and closed arms were analyzed. Results were given as ratio of time spent on open arms to total time and time spent in closed arms to total time.

\section{Western Blot}

Animals were asphyxiated with carbon dioxide, decapitated and the brains were rapidly extracted. Both right and left hippocampi and striata were dissected. Basic procedure described in earlier was followed (22). In short; tissues were homogenized with lysis buffer and protease inhibitor cocktail. Protein concentration was determined using BCA protein assay kit (23225, Thermo Fisher Scientific). Samples were centrifuged with LDS Sample buffer (NP0008, Thermo Fisher Scientific, USA) and $\beta$-mercaptoethanol at 2,500 rpm, then boiled for 5 minutes at $90{ }^{\circ} \mathrm{C}$ and rapidly cooled down. Protein separation was performed at $90 \mathrm{~V}$ for 120 minutes, on $4-12 \%$ sodium dodecyl sulfatepolyacrylamide gels (Nu-PAGETM $4-12 \%$ bis-tris, Thermo Fisher Scientific, USA) using proper running buffer. Then proteins were electrotransferred to polyvinylidene fluoride membranes. Blocking was performed for 1 hour with $5 \%$ non-fat dry milk containing buffer solution. After blocking, membranes were incubated either with anti- $\alpha$-syn primary antibody (1:1000, ab80627, Abcam) or anti-synapthophysin primary antibody (1:1500, S 5768, Sigma Aldrich) overnight or as a loading control with anti-beta-tubulinIII for 40 minutes at $+4{ }^{\circ} \mathrm{C}$. After washing in tris-buffered saline (TBS) -tween solution, membranes were incubated with one of the following secondary anti-bodies; anti-mouse or anti-rabbit (7076 and 7074 , Cell signalling technology Inc.) at room temperature (RT) for 1h. Membranes were washed gently in TBS-tween. Signal was detected with a ready-to-use kit (34095, Thermo Scientific) and with the imaging device Image Station 4000MM (Kodak). Band intensities were measured by Image J 1.49v (NIH, USA). The results were given as the ratio of optical densities of each band to that of beta-tubulin III.

\section{Immunohistochemistry}

Under terminal anesthesia, animals were perfused transcardially with heparine followed by $4 \%$ paraformaldehyde infusion. Brains were cut into $35 \mu \mathrm{m}$-thick coronal slices with microtome (Leica SM2000 R, Leica Biosystems). Immunohistochemical staining was performed with Acu-Stain HRP Kit (52-0003, Genemed) on free-floating slices. All steps were carried out at RT as described earlier (22). In short, slices were rinsed with Tris- $\mathrm{HCl}$ solution then quenched for 20 minutes and rinsed again with Tris buffer. Then they were pre-incubated with blocking solution from the kit for 10 minutes. After blocking, slices were incubated with monoclonal anti- $\alpha$-syn (1:1000, ab80627, Abcam) or antityrosine hydroxylase (TH) (1:1000, ab75875, Abcam) antibodies overnight, rinsed 3 times and incubated with biotinylated secondary anti-body solution from the kit for 10 minutes. After rinse, slices were incubated with streptavidin-peroxidase complex for 10 minutes and rinsed for the last time, then they were developed by 3,3-diaminobenzidine as a chromogen and $\mathrm{H}_{2} \mathrm{O}_{2}$ as a catalyst (Power-StainTM 1.0 Poly HRP DAB Kit, Genemed), mounted on slides and cover slipped with DPX mounting medium.

\section{Statistical analysis}

Data were presented as mean \pm standard error of the mean. The significance threshold was set at 0.05. One-Way ANOVA was used for multiple comparisons. Post hoc analyses were made either by Tukey's or Sidak test. All data were analyzed in Graphpad PRISM v6.0 software. 


\section{Results}

Motor and Cognitive Behavioral Changes Due to Alfasynuclein Overexpression in $\mathrm{SN}$ and/or DG

Open field locomotor activity test showed no difference between the groups in terms of basal locomotor activity (Figure 1C, D). In $\mathrm{CT}$, the ratio of contralateral forelimb contacts to total contacts were lower in all $\alpha$-syn groups compared to naïve controls however, it did not reach statistical significane (Figure 1E). AIRT, the number of partial rotations were higher in $\mathrm{SN}_{\alpha \text {-syn }}$ group and this difference was statistically significant compared to naive control and $\mathrm{SN}+$ $\mathrm{DG}_{\alpha \text {-syn }}$ groups $\left({ }^{*} \mathrm{p}<0.05 \mathrm{SN}_{\alpha \text {-syn }}\right.$ vs naive, $\# \mathrm{p}<0.05 \mathrm{SN}_{\alpha \text {-syn }}$ vs $\mathrm{SN}+\mathrm{DG}_{\alpha \text {-syn }}$; Figure $\left.1 \mathrm{~F}\right)$. Thus, unilateral $\alpha$-syn overexpression in SN caused only mild unilateral motor impairment.

We tested the short-term memory by NOR test. The recognition ability of $\mathrm{DG}_{\alpha \text {-syn }}$ group which was shown by spending less time with the novel object, was significantly lower than $S N+D_{\alpha \text {-syn }}$ group but not than controls (*p<0.05 $\mathrm{DG}_{\alpha-\text { syn }} \mathrm{vs} \mathrm{SN}+\mathrm{DG}_{\alpha-}$ syn; Figure 2A). In addition, this decrease in cognition was not observed in $\mathrm{SN}_{\alpha \text {-syn }}$ group ( $\mathrm{p}>0.05$; Figure $2 \mathrm{~A}$ ), so $\alpha$-syn injection directly to DG could be essential for cognitive impairment.

The learning curves of MWM showed that all groups achieved the learning phase, which was finding the platform less than 120 seconds at the end of fourth day (Figure 2B). In the probe trial, latency to find the platform was highest in $\mathrm{DG}_{\alpha \text {-syn }}$ group and $\mathrm{SN}_{\alpha-}$ syn and $\mathrm{SN}+\mathrm{DG}_{\alpha \text {-syn }}$ groups slightly spent more time compared to controls, however, without statistical significance (Figure 2C). The time spent in the platform area was similar between groups (Figure 2D) confirming that there was no motor impairment which may have had an impact on the swimming ability of the animals. $\mathrm{DG}_{\alpha \text { - }}$ syn pathology could be important for spatial learning.

In sucrose preference test, sucrose solution consumption of $\mathrm{SN}_{\alpha \text {-syn }}$ group was significantly lower than $\mathrm{SN}+\mathrm{DG}_{\alpha \text {-syn }}$ group, whereas it was significantly higher in $D_{\alpha-\text {-syn }}$ group compared to naive controls $\left({ }^{*} \mathrm{p}<0.05 \mathrm{SN}_{\alpha \text {-syn }}\right.$ vs $\mathrm{SN}+\mathrm{DG}_{\alpha \text {-syn }}, \# \mathrm{p}<0.05$ $\mathrm{DG}_{\alpha \text {-syn }}$ vs controls; Figure $2 \mathrm{E}$ ), thus $\mathrm{SN}_{\alpha \text {-syn }}$ pathology could be more related to anhedonia.

In EPM test, $\mathrm{DG}_{\alpha \text {-syn }}$ animals spent the most time in the open arms but it was only significant compared to $\mathrm{SN}+\mathrm{DG}_{\alpha-}$ syn animals $\left(\mathrm{p}<0.05 \mathrm{DG}_{\alpha \text {-syn }} \mathrm{vs} \mathrm{SN}+\mathrm{DG}_{\alpha \text {-syn }}\right.$; Figure $\left.2 \mathrm{~F}\right)$. Even though $\mathrm{SN}_{\alpha \text {-syn }}$ group spent less time than controls and $\mathrm{SN}+\mathrm{DG}_{\alpha \text { - }}$ syn group, it did not reach statistical significance $(\mathrm{p}>0.05$; Figure $2 \mathrm{~F}$ ), thus DG a $\alpha$-syn pathology could be more related to anxiety.

Morphological Changes due to Alfa-synuclein Overexpression in SN and/or DG

Immunoblot analysis revealed $14 \mathrm{kDa}$ bands in striata of $\mathrm{SN}$ and SN + DG groups and hippocampi of DG and SN + DG groups
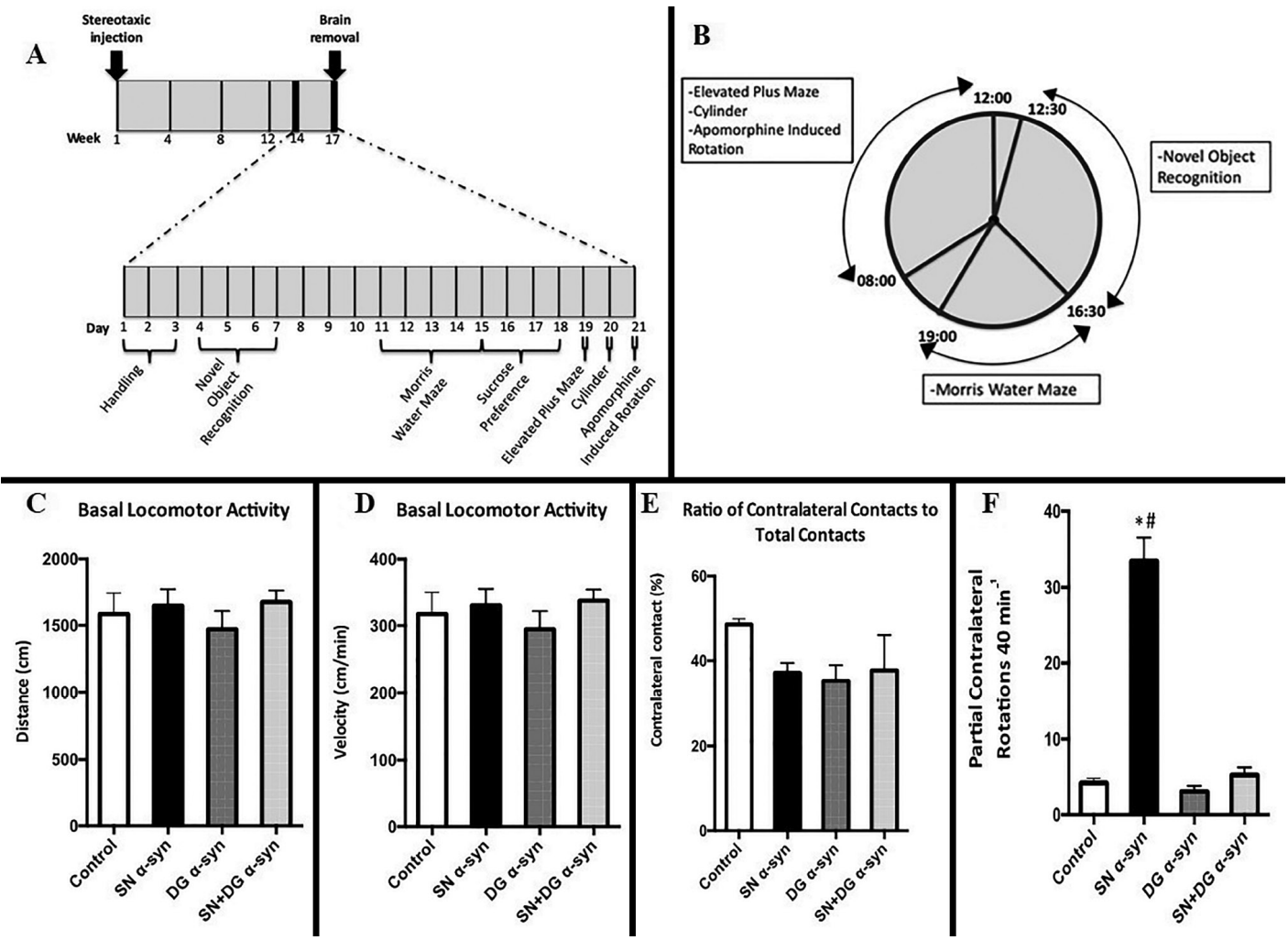

Figure 1. Study timeline and motor tests results. A) Experimental design, B) time slots for behavioral and motor tests, C) distance moved and D) velocity in Basal Locomotor Activity Test did not differ across groups, $\mathrm{n}$ (control)=10, $\mathrm{n}(\mathrm{SN} \alpha$-syn) $=11, \mathrm{n}(\mathrm{DG} \alpha$-syn) $=4, \mathrm{n}(\mathrm{SN}+\mathrm{DG} \alpha$-syn) $=5$; p $>0.05, \mathrm{E})$ in cyclinder test; decreased contralateral forelimb use in $\alpha$-syn injected animals was not significant compared to the control. $\mathrm{n}=12, \mathrm{n}(\mathrm{SN} \alpha$-syn) $=10$, $\mathrm{n}(\mathrm{DG} \alpha$-syn $)=9, \mathrm{n}(\mathrm{SN}+\mathrm{DG} \alpha$-syn $)=9 ; \mathrm{p}>0.05$. F) $\alpha$-syn injection to solely SN induces a robust partial turning behavior, while injections to SN and DG in combination lack the same outcome $\mathrm{n}=14, \mathrm{n}(\mathrm{SN} \alpha$-syn $)=11, \mathrm{n}(\mathrm{DG} \alpha$-syn $)=10, \mathrm{n}(\mathrm{SN}+\mathrm{DG} \alpha$-syn $)=11 ; \mathrm{p} *<0.05$ vs. control, $\mathrm{p} \#<0.05$ vs. SN + DG $\alpha$-syn, All analysis were performed using One-Way ANOVA followed by Sidak's multiple comparison test. Data were presented as mean \pm SEM SN: Substantia nigra, DG: Dentate gyrus, $\alpha$-syn: Alpha-synuclein, SEM: Standard error of the mean 
confirming that $\alpha$-syn overexpression was successful in the target areas (Figure 3A). Immunohistochemical analysis showed distinct patterns of $\alpha$-syn overexpression. In $\mathrm{SN}$ and striatum, $\alpha$-syn labelling was widespread and unilateral, restricted only to the side of injection, whereas in hippocampus it was bilateral, being more prominent on the injection side (Figure 3B).

In order to assess the degree of neuronal loss; nigral and striatal sections from SN and SN + DG groups were stained with anti-TH and hippocampal sections from DG and SN + DG groups, with anti-NeuN anti-bodies. In $\alpha$-syn animals, unilateral loss of $\mathrm{TH}$ immunoreactivity was observed both in $\mathrm{SN}$ and striatum (Figure 4) while in the hippocampus no such difference in NeuN labelling was detected between two sides (data not shown).

For the assessment of synaptic integrity, synaptophysin levels in striatum and/or hippocampus were measured by Western blotting. There was a decrease in synaptophysin levels in all $\alpha$-syn groups compared to naïve controls although this difference reached

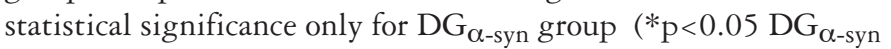
vs. $\mathrm{SN}+\mathrm{DG}_{\alpha-\text {-syn }}, \# \mathrm{p}<0.05 \mathrm{DG}_{\alpha \text {-syn }}$ vs. control; Figure 5).

\section{Discussion}

Our primary aim was to establish an animal model that mimicked both motor and NMS of PD. We chose AAV approach to induce $\alpha$-syn pathology in SN and/or DG and then conducted a set of behavioral tests. We further assessed whether molecular changes were related to motor and/or non-motor impairments.

In PD NMS affect patient's life standards as much as motor symptoms. After stage IV, PD patients start to have cognitive problems (23). Dementia, which is seen in the late-stage of $\mathrm{PD}$, is known to be related to the involvement of hippocampal subregions. The relation between hippocampal pathology and neuropsychiatric non-motor aspects of PD such as cognitive dysfunction, psyhcosis and anxiety have been shown in several studies $(24,25,26,27)$. In a study about $\alpha$-syn pathology in the hippocampus, DG and specifically CA2 region were shown to be more vulnerable to $\alpha$-syn involvement in both human and transgenic animals (25). In other studies it has been shown that, especially D1 receptor mediated dopaminergic pathways in the hippocampus are important in spatial learning and memory (24,28). In fact, when we planned targeting hippocampal complex for AAV-mediated $\alpha$-syn overexpression, the first injection site we had chosen was entorhinal cortex (EC), depending on the postmortem and experimental data. But unfortunately, despite our rigorous attempts, we had failed to target EC consistently because of technical difficulties. Since our aim was to study the impact of induced $\alpha$-syn pathology in hippocampus proper, we had changed our target to DG, as being the main projection area of EC in hippocampal circuitry.

$\alpha$-syn overexpression in target areas was confirmed by immunoblotting and IHC. Variable expression levels were

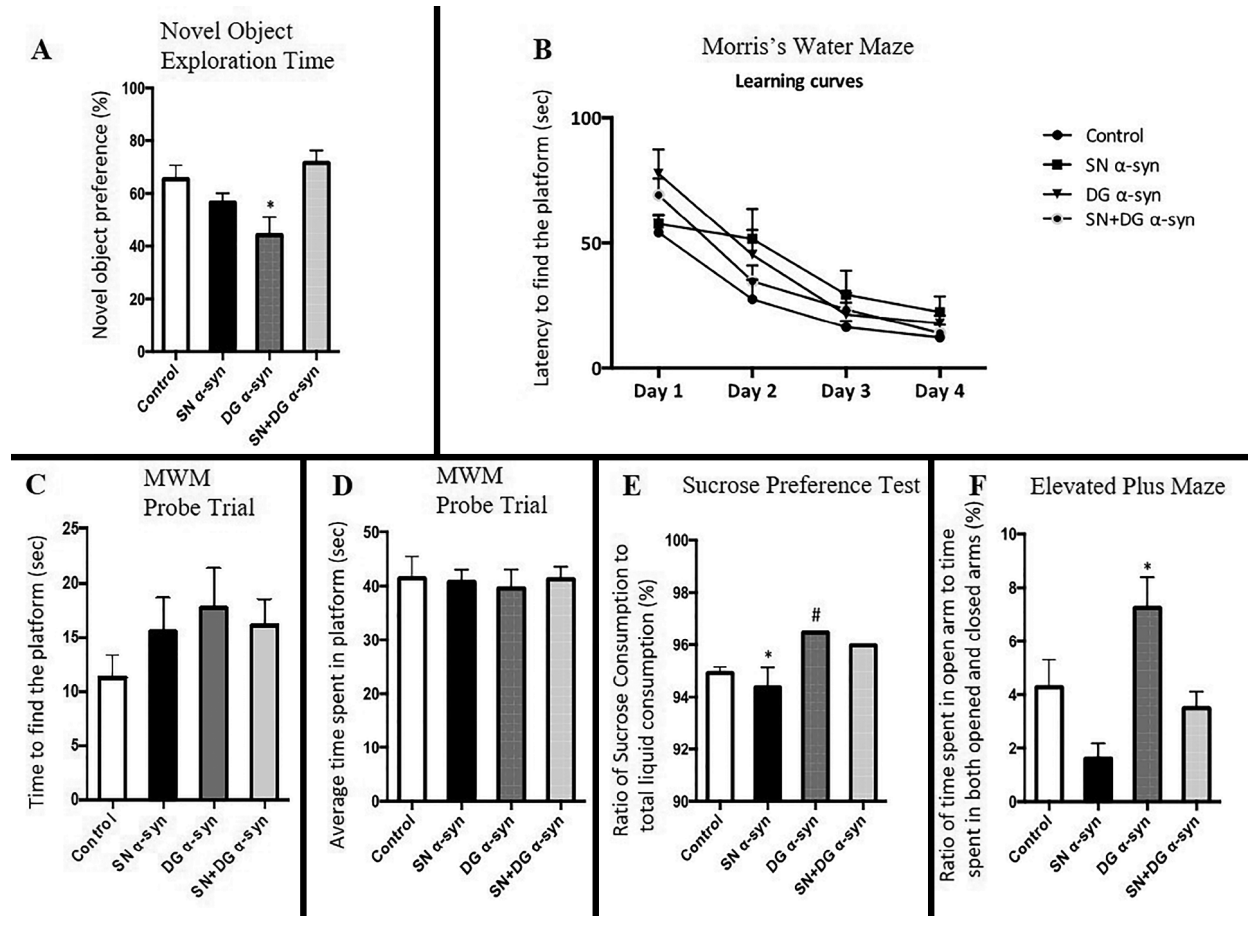

Figure 2. Behavioral test results. A) Short-term memory was found to be slightly impaired in $\mathrm{SN}$ - and DG-alpha-synuclein groups. $\mathrm{n}$ (control)=12, $\mathrm{n}$ $(\mathrm{SN} \alpha$-syn $)=11, \mathrm{n}(\mathrm{DG} \alpha$-syn $)=4, \mathrm{n}(\mathrm{SN}+\mathrm{DG} \alpha$-syn $)=11 ; \mathrm{p}^{*}<0.05$ vs $\mathrm{SN}+\mathrm{DG} \alpha$-syn. B) Average latencies of all groups on the training days. $\alpha$-syn expression did not cause significant alterations in Morris Water Maze performance. C) Latency to find the platform on the $5^{\text {th }}$ day. $\mathrm{n}($ control) $=12, \mathrm{n}$ $(\mathrm{SN} \alpha$-syn $)=11, \mathrm{n}(\mathrm{DG} \alpha$-syn $)=10, \mathrm{n}(\mathrm{SN}+\mathrm{DG} \alpha$-syn $)=12$. D) Time spent in the platform area on the $5^{\text {th }}$ day. $\mathrm{n}(\mathrm{control})=8, \mathrm{n}(\mathrm{SN} \alpha$-syn $)=5, \mathrm{n}(\mathrm{DG}$ $\alpha$-syn $)=4, \mathrm{n}(\mathrm{SN}+\mathrm{DG} \alpha$-syn $)=6 . \mathrm{p}>0.05$. E) Effect of $\alpha$-syn overexpression on sucrose consumption. $\mathrm{n}(\mathrm{control})=14, \mathrm{n}(\mathrm{SN} \alpha$-syn) $=6, \mathrm{n}(\mathrm{DG} \alpha$-syn $)=6$, $\mathrm{n}(\mathrm{SN}+\mathrm{DG} \alpha$-syn $)=6 ; \mathrm{p}^{*}<0.05$ vs. $\mathrm{SN}+\mathrm{DG} \alpha$-syn, $\mathrm{p} \#<0.05$ vs control. F) Effect of $\alpha$-syn overexpression on anxiety-like behavior $\mathrm{n}($ control) $=13$, $\mathrm{n}$ $(\mathrm{SN} \alpha$-syn $)=9, \mathrm{n}(\mathrm{DG} \alpha$-syn $)=9, \mathrm{n}(\mathrm{SN}+\mathrm{DG} \alpha$-syn $)=11 ; \mathrm{p}^{*}<0.05 \mathrm{DG} \alpha$-syn vs SN + DG $\alpha$-syn. All analysis were performed using One-Way ANOVA followed by Sidak's multiple comparison test. Data were presented as mean \pm SEM SN: Substantia nigra, DG: Dentate gyrus, MWM: Morris water maze 
observed in striata and hippocampi. As previously reported, this could be due to variable transduction characteristics of the AAV6 serotype in distinct brain regions (29).

Motor impairment was assessed by CT and AIRT. In CT, contralateral forelimb use did not show significant difference in any of the groups compared to controls. This result might be due to insufficient striatal dopaminergic denervation leading to just subclinical changes $(9,10)$. In AIRT, only SN $\alpha$-syn animals displayed circling behaviour, but the number of turns were found to be low. Again, this might be due to subtreshold striatal denervation which did not cause significant dopaminergic receptor supersensitivity. To our surprise, apomorphine did not induce rotational behaviour in $\mathrm{SN}+\mathrm{DG}_{\alpha \text {-syn }}$ animals. As it was previously put forth, hippocampus and striatum interact with each other, but the molecular mechanisms were not yet clear $(30,31,32)$. This interaction might be responsible for the suppression of denervation supersensitivity.

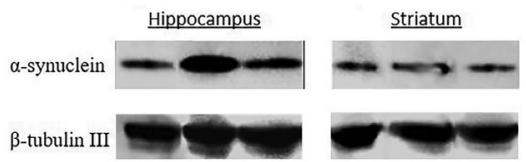

B

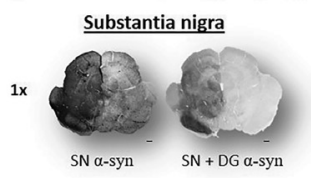

a-Synuclein immunohistochemical staining
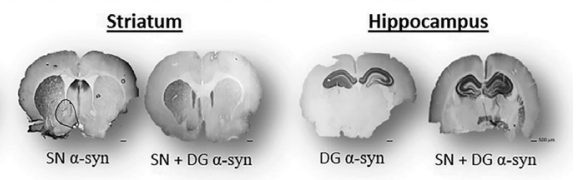

Figure 3. Alpha-synuclein ( $\alpha$-syn) overexpression in all targeted areas. A) Representative Western blots showing expression in hippocampal and striatal tissues. B) Immunohistochemistry staining showed that the $\alpha$-syn was present unilaterally in striatum and SN and bilaterally in hippocampus (images taken at 1x magnification, scalebars: $500 \mu \mathrm{m}$ ) SN: Substantia nigra, DG: Dentate gyrus

\section{SN alpha-synuclein alpha-synuclein}

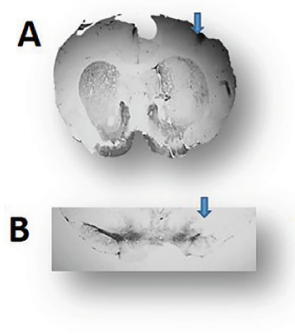

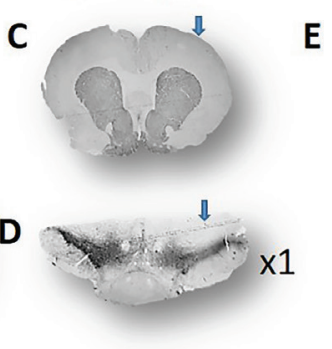

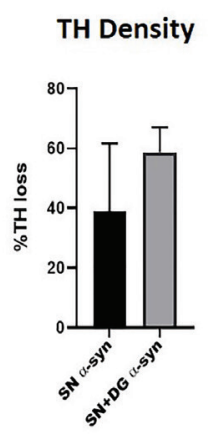

Figure 4. Immunohistochemical tyrosine hydroxylase staining of SN $\alpha$-syn injected groups A) striatum, and B) substantia nigra in which indicated TH terminal loss in the pointed side of arrow. SN + DG $\alpha$-syn injected groups, C) striatum, and D) substantia nigra in which contrary to only SN injection, detectable TH terminal loss was not seen qualitatively in these sections, E) quantitative analysis of TH density and \% TH density loss compared to intact side by ImageJ

SN: Substantia nigra, DG: Dentate gyrus, $\alpha$-syn: Alpha-synuclein, TH: Tyrosine hydroxylase
Memory function was evaluated in NOR test. Short-term memory performances of $\alpha$-syn animals did not show significant difference compared to controls. At present, neurobiological basis of cognitive impairment in PD is not fully known. Preclinical and clinical data indicate involvement of several brain regions including hippocampus $(33,34)$, prefrontal cortex $(35,36)$ and basal ganglia (24). We thought that although unilateral AAV- $\alpha$-syn injection led to bilateral and widespread $\alpha$-syn overexpression in the hippocampus, it did not induce sufficient damage in memory related networks in the medial temporal lobe structures and frontostriatal circuits in our study. Besides, it was also possible that compensation mechanisms which took over in time, played a role preserving the memory functions.

Visuospatial learning and memory were tested by MWM. In probe trial, latencies to find the platform were found to be increased in all $\alpha$-syn groups compared to controls but this did not reach statistical significance. Besides, average time spent in the platform area was similar between groups. It is known that both hippocampal and striatal memory systems have a role in spatial navigation (37). But, unlike cued version of MWM, SN lesions do not affect test performance in the spatial version. Thus, our results from $\mathrm{SN}_{\alpha \text {-syn }}$ animals were consistent with the available data. Regarding the preserved memory in $\mathrm{DG}_{\alpha \text {-syn }}$ and $\mathrm{SN}+$ DG $\alpha$-syn groups, a plausible explanation could be that, bilateral and widespread $\alpha$-syn expression in the hippocampus did not lead to functional consequences in spatial learning and memory (38).
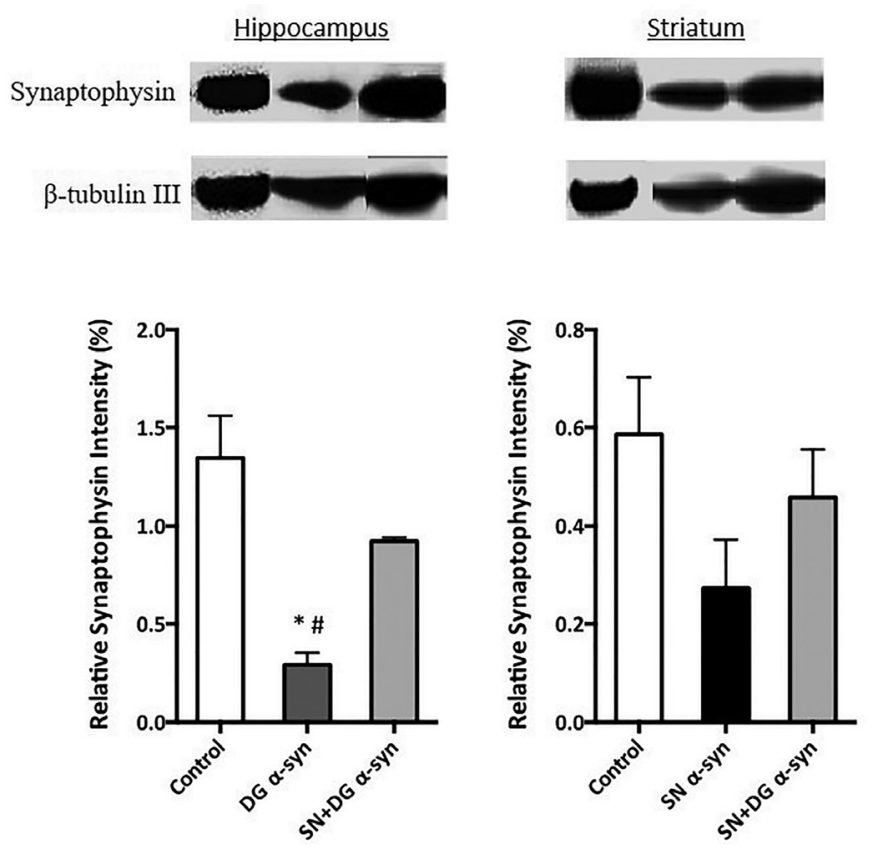

Figure 5. Effect of alpha-synuclein ( $\alpha$-syn) overexpression on synaptophysin levels. AAV- $\alpha$-syn injection to DG or $\mathrm{SN}$ alone resulted in greater decrease of synaptophysin levels compared to injection to both $\mathrm{SN}$ and DG. Hippocampus; n (control) $=5, \mathrm{n}(\mathrm{DG} \alpha$-syn $)=4, \mathrm{n}(\mathrm{SN}+$ DG $\alpha$-syn $)=5$, striatum; n (control) $=5, \mathrm{n}(\mathrm{DG} \alpha$-syn $)=5, \mathrm{n}(\mathrm{SN}+\mathrm{DG}$ $\alpha$-syn) $=5 ; \mathrm{p}^{*}<0.05$ DG $\alpha$-syn vs SN + DG $\alpha$-syn, $\mathrm{p} \#<0.05$ DG $\alpha$-syn vs control. One-Way ANOVA followed by Tukey's multiple comparison test. The data were presented as mean \pm SEM

SN: Substantia nigra, DG: Dentate gyrus, SEM: Standard error of the mean 
Anhedonia was assessed by SPT. $\mathrm{SN}_{\alpha \text {-syn }}$ animals showed a decreased tendency to consume sucrose solution compared to controls. This finding was consistent with the past studies (39) and could be explained by the fact that SPT measured consummatory but not anticipatory anhedonia. Consummatory anhedonia is suggested to be related to $\mu$ opioid, endocannabinoid, GABAA receptors, whereas dopamine is more connected with anticipatory anhedonia (40). On the other hand, as we observed a tendency to anhedonic behaviour, it was tempting to suggest that striatal dopaminergic deficit also contributed to consummatory anhedonia. Our analysis also revealed a significantly higher sucrose solution intake in both $\mathrm{DG}_{\alpha \text {-syn }}$ and $\mathrm{SN}+\mathrm{DG}_{\alpha \text {-syn }}$ groups relative to control, being significant in the first one. There is evidence that hippocampal lesions result in higher response rates to rewarding stimuli (41). This finding was suggested to be related to modulation of NAc by hippocampus (41). In support of this view, it is possible that AAV- $\alpha$-syn injection to DG causes hedonic behaviour by disrupting glutamatergic modulation of NAc.

Anxiety was measured using EPM test. Anxiety levels of $\mathrm{SN}_{\alpha \text {-syn }}$ group tended to be higher than controls. It is clear that dopaminergic dysfunction contributes to anxiety (42). DG $\mathrm{D}_{\alpha \text {-syn }}$ group displayed reduced anxiety behavior compared to controls. Past studies, including a recent study by our group, reported that bilateral hippocampal lesions resulted in decreased anxiety $(22,43)$. As the reduction we found was not significant, it was likely that unilateral hippocampal $\alpha$-syn injection was not sufficient for a complete anxiolytic effect (44). On the other hand, it is intriguing to think that tendency to reduced anxiety might be the result of interneuronal spreading of $\alpha$-syn to the contralateral hippocampus leading to a bilateral expression of $\alpha$-syn (Figure 3). Considering the opposite effects of $\alpha$-syn overexpression in SN and DG, it is possible not to observe any changes with overexpression in both areas.

Synaptic loss was investigated by measuring synaptophysin levels in striata and hippocampi in experimental groups accordingly. $\alpha$-syn overexpression led to a decrease in synaptophysin levels in all groups. It was only significant in hippocampus of $\mathrm{DG}_{\alpha \text {-syn }}$ animals compared to controls and also compared to $\mathrm{SN}+\mathrm{DG}_{\alpha \text {-syn }}$ animals. Interestingly, regardless of significant levels, the decrease was lower in both hippocampus and striatum of $\mathrm{SN}+\mathrm{DG}_{\alpha \text {-syn }}$ animals, compared to $\mathrm{DG}_{\alpha \text {-syn }}$ and $\mathrm{SN}_{\alpha \text {-syn }}$ animals, respectively. As outlined in the multiplememory systems theory, hippocampus and basal ganglia are both involved in processing different types of memory. It is known that these structures do not work in isolation, in fact interfere with each other. Evidence shows that there is a bidirectional competition between hippocampal and striatal memory systems, such that damage to one system leads to improvement in another, and vice versa $(30,31)$. Indeed, from the current study, NOR (Figure 2A) and MWM (Figure 2C) data might be the indicators of such interaction. It was not clear yet how these two systems influenced each other at the cellular level, however it was argued that altered synaptic plasticty, more spesifically cAMP/CREB levels, in those structures might contribute to bidirectional competition $(31,44,45,46)$. Thus, we may suggest that synaptophysin might be involved in the interplay between hippocampus and striatum, and the pathological changes in one might result in elevated synaptophysin levels in another, due to a compensatory increase in synapse formation.

\section{Study Limitations}

There are some limitations of this study. First, unilateral $\alpha$-syn injection might not be sufficient to induce neurodegeneration at an adequate level in the target regions. Second, when evaluating NMS, it should be considered that hippocampus and striatum interact with each other and they both might be involved in neuropathology of NMS. Third, brain regions, other than hippocampus and basal ganglia, and non-dopaminergic systems also have an impact on NMS and these may be involved as targets of AAV- $\alpha$-syn injections for furher combinations. Future research that overcomes above mentioned limitations will give us valuable insights about the pathophysiology of NMS in PD.

\section{Conclusion}

In this model, our main objective was to investigate the relation between NMS and unilateral hippocampal and nigral $\alpha$-synucleinopathy. Although $\alpha$-syn overexpression in the target brain regions was successful, the NMS that were tested in detail did not show much significant changes. The data presented here may provide basis for similar studies in the future.

\section{Acknowledgements}

This study originates from Sevgi Uğur Mutluay's Master's thesis.

We would like to thank to all of the members of Hacettepe University Institute of Neurological Sciences and Psychiatry Brain Research Laboratory for their support and help to use all the equipment's in the lab.

We would like to thank Mesut Firat, Necati Şengönül and Erdoğan Aksay for their technical support.

Ethics

Ethics Committee Approval: All experimental procedures were approved by Hacettepe University Local Animal Ethics Committee (decision number: 2014/44-10) and performed in compliance with national and local animal care and use guidelines.

Informed Consent: Not applicable.

Peer-review: Externally peer-reviewed.

\section{Authorship Contributions}

Surgical and Medical Practices: S.U.M., E.Ç., Concept: A.U., B.E., B.C.T., Design: S.U.M., E.Ç., G.Y.Ç., B.C.T., Data Collection or Processing: S.U.M., E.Ç., Analysis or Interpretation: S.U.M., E.Ç., B.C.T., Literature Search: S.U.M., Writing: S.U.M.

Conflict of Interest: No conflict of interest was declared by the authors.

Financial Disclosure: This study was supported by Hacettepe University Scientific Research Projects Coordination Unit (014 D08 301 007-701).

\section{References}

1. Calabresi P, Castrioto A, Di Filippo M, Picconi B. New experimental and clinical links between the hippocampus and the dopaminergic system in Parkinson's disease. Lancet Neurol 2013;12:811-821.

2. Breydo L, Wu JW, Uversky VN. A-synuclein misfolding and Parkinson's disease. Biochim Biophys Acta 2012;1822:261-285.

3. Gubellini P, Kachidian P. Animal models of Parkinson's disease: An updated overview. Rev Neurol (Paris) 2015;171:750-761.

4. Nouraei N, Mason DM, Miner KM, et al. Critical appraisal of pathology transmission in the alpha-synuclein fibril model of Lewy body disorders. Exp Neurol 2018;299(Pt A):172-196. 
5. Dehay B, Vila M, Bezard E, Brundin P, Kordower JH. Alpha-synuclein propagation: New insights from animal models. Mov Disord 2016;31:161168.

6. Kirik D, Rosenblad C, Burger C, et al. Parkinson-like neurodegeneration induced by targeted overexpression of alpha-synuclein in the nigrostriatal system. J Neurosci 2002;22:2780-2791.

7. Eslamboli A, Romero-Ramos M, Burger C, et al. Long-term consequences of human alpha-synuclein overexpression in the primate ventral midbrain. Brain 2007;130(Pt 3):799-815.

8. Theodore S, Cao S, McLean PJ, Standaert DG. Targeted overexpression of human alpha-synuclein triggers microglial activation and an adaptive immune response in a mouse model of Parkinson disease. J Neuropathol Exp Neurol 2008;67:1149-1158.

9. Decressac M, Mattsson B, Lundblad M, Weikop P, Bjorklund A. Progressive neurodegenerative and behavioural changes induced by AAV-mediated overexpression of alpha-synuclein in midbrain dopamine neurons. Neurobiol Dis 2012;45:939-953.

10. Gombash SE, Manfredsson FP, Kemp CJ, et al. Morphological and behavioral impact of AAV2/5-mediated overexpression of human wildtype alphasynuclein in the rat nigrostriatal system. PLoS One 2013;8:e81426.

11. Oliveras-Salva M, Van der Perren A, Casadei N, et al. rAAV2/7 vectormediated overexpression of alpha-synuclein in mouse substantia nigra induces protein aggregation and progressive dose-dependent neurodegeneration. Mol Neurodegener 2013;8:44.

12. Van der Perren A, Toelen J, Casteels C, et al. Longitudinal follow-up and characterization of a robust rat model for Parkinson's disease based on overexpression of alpha-synuclein with adeno-associated viral vectors. Neurobiol Aging 2015;36:1543-1558.

13. Bourdenx M, Dovero S, Engeln M, et al. Lack of additive role of ageing in nigrostriatal neurodegeneration triggered by alpha-synuclein overexpression. Acta Neuropathol Commun 2015;3:46.

14. Dehay B, Fernagut PO. Alpha-synuclein-based models of Parkinson's disease. Rev Neurol (Paris) 2016;172:371-378.

15. Aldrin-Kirk P, Davidsson M, Holmqvist S, Li JY, Bjorklund T. Novel AAVbased rat model of forebrain synucleinopathy shows extensive pathologies and progressive loss of cholinergic interneurons. PLoS One 2014;9:e100869.

16. Alvarsson A, Caudal D, Bjorklund A, Svenningsson P. Emotional memory impairments induced by AAV-mediated overexpression of human alphasynuclein in dopaminergic neurons of the ventral tegmental area. Behav Brain Res 2016;296:129-133.

17. Wan OW, Shin E, Mattsson B, et al. Alpha-synuclein induced toxicity in brain stem serotonin neurons mediated by an AAV vector driven by the tryptophan hydroxylase promoter. Sci Rep 2016;6:26285.

18. Delenclos M, Faroqi AH, Yue M, et al. Neonatal AAV delivery of alphasynuclein induces pathology in the adult mouse brain. Acta Neuropathol Commun 2017;5:51.

19. Henrich MT, Geibl FF, Lee B, et al. A53T-alpha-synuclein overexpression in murine locus coeruleus induces Parkinson's disease-like pathology in neurons and glia. Acta Neuropathol Commun 2018;6:39.

20. Niu H, Shen L, Li T, et al. Alpha-synuclein overexpression in the olfactory bulb initiates prodromal symptoms and pathology of Parkinson's disease. Transl Neurodegener 2018;7:25.

21. Paxinos G, Watson C. The Rat Brain in Stereotaxic Coordinates 7th Edition. Academic Press; 2013. Available from: https://www.elsevier.com/books/therat-brain-in-stereotaxic-coordinates/paxinos/978-0-12-391949-6

22. Cinar E, Yalcin-Cakmakli G, Saka E, et al. Modelling cognitive deficits in Parkinson's disease: Is CA2 a gateway for hippocampal synucleinopathy? Exp Neurol 2020;330:113357.

23. Braak H, Del Tredici K, Rub U, et al. Staging of brain pathology related to sporadic Parkinson's disease. Neurobiol Aging 2003;24:197-211.

24. Bonito-Oliva A, Pignatelli M, Spigolon G, et al. Cognitive impairment and dentate gyrus synaptic dysfunction in experimental parkinsonism. Biol Psychiatry 2014;75:701-710.

25. Flores-Cuadrado A, Ubeda-Banon I, Saiz-Sanchez D, de la Rosa-Prieto C, Martinez-Marcos A. Hippocampal alpha-synuclein and interneurons in Parkinson's disease: Data from human and mouse models. Mov Disord 2016;31:979-988.

26. Lenka A, Ingalhalikar M, Shah A, et al. Hippocampal subfield atrophy in patients with Parkinson's disease and psychosis. J Neural Transm (Vienna) 2018;125:1361-1372.
27. Luna E, Decker SC, Riddle DM, et al. Differential alpha-synuclein expression contributes to selective vulnerability of hippocampal neuron subpopulations to fibril-induced toxicity. Acta Neuropathol 2018;135:855-875.

28. Xing B, Kong H, Meng X, et al. Dopamine D1 but not D3 receptor is critical for spatial learning and related signaling in the hippocampus. Neuroscience 2010;169:1511-1519.

29. Aschauer DF, Kreuz S, Rumpel S. Analysis of transduction efficiency, tropism and axonal transport of AAV serotypes 1, 2, 5, 6, 8 and 9 in the mouse brain. PLoS One 2013;8:e76310.

30. Poldrack RA, Packard MG. Competition among multiple memory systems: converging evidence from animal and human brain studies. Neuropsychologia 2003;41:245-251.

31. Lee AS, Duman RS, Pittenger C. A double dissociation revealing bidirectional competition between striatum and hippocampus during learning. Proc Natl Acad Sci USA 2008;105:17163-17168.

32. Kathirvelu B, Colombo PJ. Effects of lentivirus-mediated CREB expression in the dorsolateral striatum: memory enhancement and evidence for competitive and cooperative interactions with the hippocampus. Hippocampus 2013;23:1066-1074.

33. Moriguchi S, Yabuki Y, Fukunaga K. Reduced calcium/calmodulindependent protein kinase II activity in the hippocampus is associated with impaired cognitive function in MPTP-treated mice. J Neurochem 2012;120:541-551.

34. Ho SC, Hsu CC, Pawlak CR, et al. Effects of ceftriaxone on the behavioral and neuronal changes in an MPTP-induced Parkinson's disease rat model. Behav Brain Res 2014;268:177-184.

35. Chao OY, Pum ME, Huston JP. The interaction between the dopaminergic forebrain projections and the medial prefrontal cortex is critical for memory of objects: implications for Parkinson's disease. Exp Neurol 2013;247:373-382.

36. Santos JR, Cunha JA, Dierschnabel AL, et al. Cognitive, motor and tyrosine hydroxylase temporal impairment in a model of parkinsonism induced by reserpine. Behav Brain Res 2013;253:68-77.

37. Sukumar D, Rengaswamy M, Chakravarthy VS. Modeling the contributions of Basal ganglia and Hippocampus to spatial navigation using reinforcement learning. PLoS One 2012;7:e47467.

38. de Hoz L, Moser EI, Morris RG. Spatial learning with unilateral and bilateral hippocampal networks. Eur J Neurosci 2005;22:745-754.

39. Campos FL, Carvalho MM, Cristovao AC, et al. Rodent models of Parkinson's disease: beyond the motor symptomatology. Front Behav Neurosci 2013;7:175.

40. Der-Avakian A, Markou A. The neurobiology of anhedonia and other reward-related deficits. Trends Neurosci 2012;35:68-77.

41. Chambers RA, Self DW. Motivational responses to natural and drug rewards in rats with neonatal ventral hippocampal lesions: an animal model of dual diagnosis schizophrenia. Neuropsychopharmacology 2002;27:889-905.

42. Prediger RD, Matheus FC, Schwarzbold ML, Lima MM, Vital MA. Anxiety in Parkinson's disease: a critical review of experimental and clinical studies. Neuropharmacology 2012;62:115-124.

43. Weeden CS, Roberts JM, Kamm AM, Kesner RP. The role of the ventral dentate gyrus in anxiety-based behaviors. Neurobiol Learn Mem 2015;118:143-149.

44. Padilla-Coreano N, Bolkan SS, Pierce GM, et al. Direct Ventral Hippocampal-Prefrontal Input Is Required for Anxiety-Related Neural Activity and Behavior. Neuron 2016;89:857-866.

45. Pittenger C, Fasano S, Mazzocchi-Jones D, et al. Impaired bidirectional synaptic plasticity and procedural memory formation in striatum-specific cAMP response element-binding protein-deficient mice. J Neurosci 2006;26:2808-2813.

46. Martel G, Millard A, Jaffard R, Guillou JL. Stimulation of hippocampal adenylyl cyclase activity dissociates memory consolidation processes for response and place learning. Learn Mem 2006;13:342-348. 